\title{
HAROLDO NOS CAMPOS DO SENHOR
}

Ido o poeta, resta a poesia. Terminado o homem, fragmentos de sua presença são agilizados pelos que permanecem, para refletir entre a resignação e a re-criação. De Haroldo de Campos, entre nós e através da velocidade dos meios de comunicação, um dos fragmentos mais circulados é o da sua figura enredada em livros, em seu campo de trabalho particular. A fotografia - um memento pessoal, como ele possivelmente gostaria de ver nomeado esse registro de si - o captura sereno, entre livros que projetam toda a sua potência nomeadora e transformadora do mundo. Quando pensamos em bibliotecas, pensamos em organização e em coleções de livros que, entocados e silenciosos, guardam uma conduta de dormência. Não a biblioteca de Haroldo. Nela, toda essa carga de livros parece pôr em circulação um gigantesco fluxo elétrico em ágil movimento. E talvez esta seja uma das principais características de Haroldo de Campos - a de salientar que a principal reserva de energia produzida pelos homens encontra-se

\section{ENRIQUE MANDELBAUM}

é psicanalista, doutor em Língua Hebraica, Literatura e Cultura Judaicas pela FFLCH-USP e autor de Franz Kafka: um Judaísmo na Ponte do Impossivel(Perspectiva). 
armazenada em forma de livros. Seu empenho como poeta, para além de produzir um novo traço ou aproximar um livro dos homens, era o de criar um circuito capaz de pôrem movimento a gigantesca energia que a letra escrita tem e dinamizá-la com intensidade, para agilizar os homens. Preocupava-se mais com o fenômeno poético e seu fluxo do que em produzir mais uma mensagem na gigantesca e enlouquecida tempestade de mensagens que, colidindo umas com as outras, tendem a silenciar-se no ruidoso campo comunicativo destes tempos em que a solidão dos homens ganha concretude. Com a sua partida, mais do que os homens, devem chorar os livros que, sem o dinamismo de Haroldo, tendem a apertar-se e isolar-se nas constrangedoras limitações a que a vida moderna os condena.

O gigantesco trabalho de Haroldo assume a configuração de uma galáxia povoada por uma multiplicidade de signos, constelações de símbolos e sinais, influenciando a formação ininterrupta de um vasto campo de leituras. Como leitores, diante desse campo somos pequenos. Sabemos da sua amplitude do mesmo modo como sabemos, através do brilho das estrelas, da distância que nos separa de centelhas importantes que apontam, com sua presença, para uma concepção sobre o infinito. Na formação dessa galáxia, o trabalho de tradução assume um papel importante. Para Haroldo, que tomava como língua de chegada principal o português, o poeta não poderia mais ser um fingidor, mas um tradutor. Não apenas por nosso país ser culturalmente periférico e desprovido de fortes tradições culturais próprias, mas também pelo abraço tecnológico já em pleno andamento nos anos que se seguiram à Segunda Guerra Mundial - e que, queira ou não, aperta uma nação à outra, uma língua à outra -, a tradução, mais do que um artifício, permitiria tanto a continuidade do processo de construção de nossa cultura nacional, quanto a contribuição brasileira no processo cultural global. Somos feitos de traduções. A própria idéia modernista da Semana de 22 sobre a antropofagia nada mais foi do que uma figuração do processo de tradução, que passava a ser assumido como um eixo desdobrador de nossa identidade nacional. O processo de tradução, para Haroldo, era tão amplo que, em sua concepção, confundia-se com o próprio processo de leitura e criação. Haroldo, junto com seu irmão Augusto e Décio Pignatari, foi uma das vozes mais importantes na constituição de um campo crítico-literário, de enorme importância internacional, que considera o poeta, antes de mais nada, como um leitor. E, por ser leitor, é, a um só tempo, tradutor e criador. Para ele, não só as literaturas estrangeiras devem ser traduzidas, mas é a própria criação dos autores nacionais, núcleo fundamental da literatura formadora de nossa condição brasileira, que deve também ser transcriada - como Haroldo nomeava o processo de tradução-, permanentemente. É isso, por exemplo, o que ele fez em sua brilhante leitura de Macunaíma, de Mário de Andrade, da obra de Gregório de Matos e de tantos outros.

Esse processo ininterrupto de elaboração, resultado de um olhar crítico sobre todas as manifestações da língua, só é alcançado se levarmos em consideração, de acordo com Haroldo, todo o importante arsenal teórico que permite oferecer concretude aos fenômenos da comunicação, que parecem ser, para ele, uma extensão, uma dilatação num longo processo que tem, em seu núcleo de origem, a voz e a letra humana. Cinema, televisão, rádio, teatro, jornal, revistas, folhetins, internet - tudo o que denominamos de meios de comunicação de massas - seriam prolongamentos amplificados do gesto oral e do registro escrito dos homens. O desenvolvimento da lingüística, com Jakobson à frente, bem como a própria criação literária do século XX, em especial daqueles autores que fazem de sua atividade de escrita o eixo central de sua produção - da língua e da literatura a personagem principal -, tal como James Joyce e Mallarmé, teriam proporcionado os elementos necessários para a constituição desse olhar crítico que permite materializar os fenômenos da linguagem, que ganham assim a condição de objetos a serem refletidos. Todos esses fenômenos comu- 
nicativos não são meros resultados da expressividade de um eu autoral. Ao contrário, como todo o olhar crítico da história nos ensinou, esse eu é produzido pelos fenômenos comunicativos que circulam ao seu redor e o atravessam em sua própria criação, numa dialética complexa em que obras e autor produzem-se mutuamente. Haroldo é do século XX, conhece os avanços tecnológicos que permitem, se assim alguém o desejar, pôr um livro à disposição de todos os homens instantaneamente, si- apenas os meios, desprovidos de qualquer mensagem a não ser a da própria reiteração da ação do meio, visando legitimar-se para ganhar permanência. Essa fotografia de Haroldo rodeado de livros, e não de televisores, jornais ou rádios, aparelhos de som, etc., expressa o que estamos tentando dizer. Haroldo nunca se afastou dos livros, e talvez pudéssemos dizer que nunca gostaria que livros e homens se afastassem.

Dizíamos antes que Haroldo construiu uma galáxia, e que somos pequenos para

\section{O poeta em seu} escritório

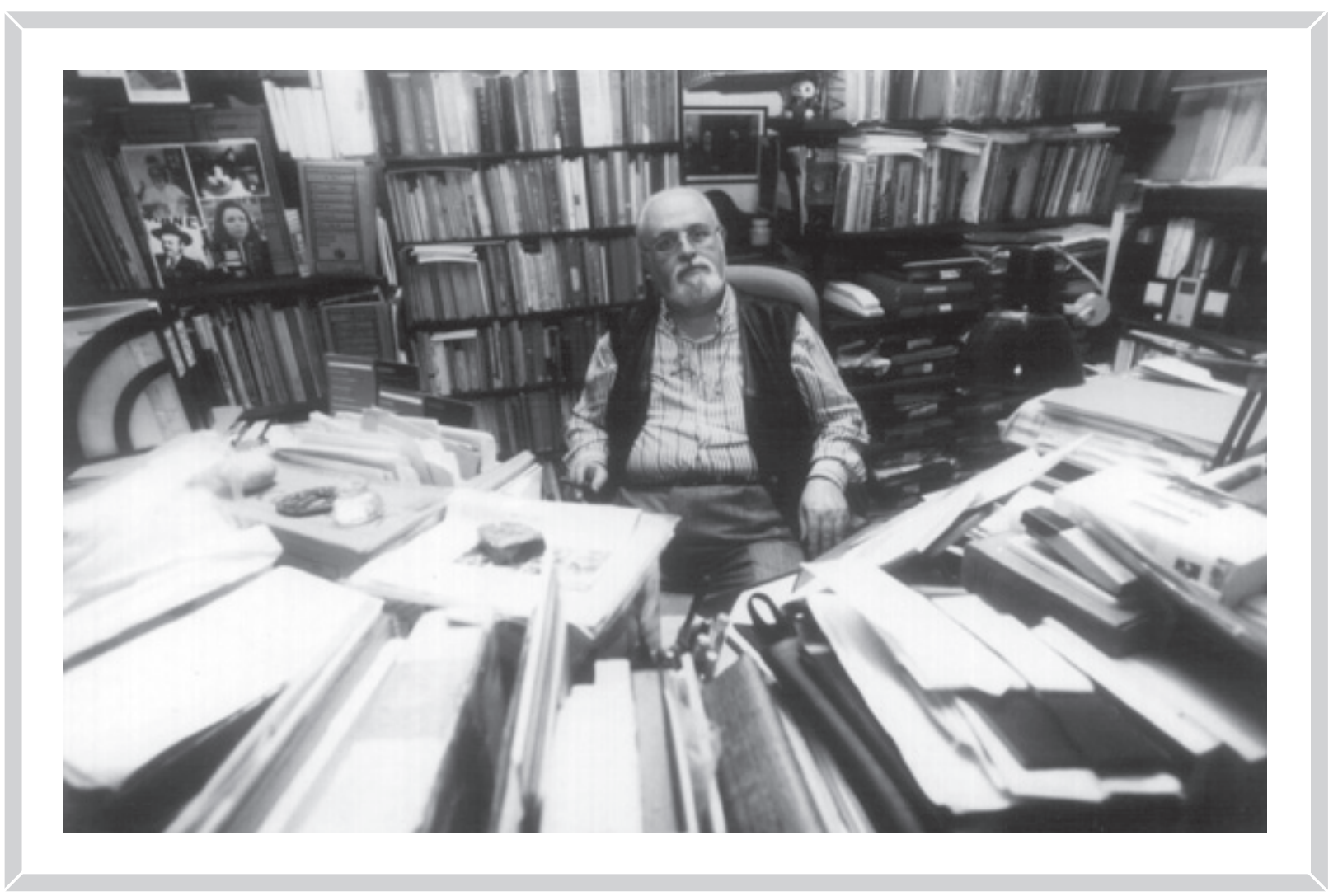

multaneamente. Mas ele sabe também que a televisão não leva um livro para casa, que o enunciado se metamorfoseia em outra coisa. O meio é a mensagem, dizia McLuhan. E Haroldo, que em igual intensidade admirava e temia os meios de comunicação, sabia que nenhum deles substitui o livro enquanto livro. Ou melhor, nesse processo sem volta de ampliação da nuvem comunicativa, que tende a ofuscar sua origem no livro, na palavra e no gesto humano, a extensão também significa uma extinção. Os meios tendem a transmitir desbravá-la em toda a sua extensão. Mas Borges nos ensinou que um livro tem a complexidade da galáxia, e nossos concretistas nos mostraram, de forma ainda mais radical, que uma palavra tem a complexidade da galáxia. Por isso, talvez, se adentrarmos a tradução que Haroldo fez do Qohélet/O-que-Sabe (1), possamos melhor discernir um pouco de toda essa galáxia. A idéia de que a parte tem a complexidade do todo é muito antiga. As íntimas relações entre o microcosmo e o macrocosmo mergulham na história, e nós
1 Haroldo de Campos, Qohélet/ O-que-Sabe - Eclesiastes: Poema Sapiencial, com colaboração especial de J. Guinsburg, São Paulo, Perspectiva, 1991. 
podemos encontrar um precursor dessa fala de Borges - por que não? - em Gregório de Matos, em seu poema “Ao Braço do Mesmo Menino Jesus quando Appareceo” (2):

"O todo sem a parte não é todo,

A parte sem o todo não é parte,

Mas se a parte o faz todo, sendo parte, Não se diga que é parte, sendo todo".

Nessa primeira estrofe está a tese central do que o poeta quer nos transmitir: toda parte contém o todo do qual é parte. Isso vale para o livro de Borges, isso vale para a palavra compreendida a partir do poderoso crivo teórico dos concretistas. Mas minimalizar o poema de Gregório de Matos a essa primeira estrofe é silenciar a profunda implicação teológica a serviço da qual Gregório de Matos integra visceralmente parte e todo. Por isso, apesar de não ter propriamente a ver com este trabalho, permitam-nos pôr o poema por inteiro, que continua:

"Em todo Sacramento está Deus todo, E todo assiste inteiro em qualquer parte, E feito em partes todo em toda a parte, Em qualquer parte sempre fica o todo.

O braço de Jesus não seja parte, Pois que feito Jesus em partes todo, Assiste cada parte em sua parte.

Não se sabendo parte deste todo, Um braço, que lhe acharam, sendo parte, Nos disse as partes todas deste todo".

Nesse barroquismo que entrelaça parte e todo, Sacramento e Deus, um braço de Jesus, sem se saber, nos diz do todo de Jesus. Esse final é importante: a parte, sem se saber parte do todo, nos diz sobre as partes todas desse todo. Porque nós sabemos, diante da parte, que é parte do todo. Graças à parte. Erguendo o poema de Gregório de Matos a um modelo, podemos dizer que Haroldo trabalha dentro desse modelo, fazendo da parte, mais do que uma ponte para o todo, um fragmento para apresentá-lo. tica, 3e. ed., Rio de Janeiro Record, 1992. obra completa, levando radicalmente em consideração a idéia concretista de que a parte reproduz a complexidade do todo. Ele não traduziu todo o Fausto de Goethe, somente um fragmento. Também não traduziu toda a Bíblia, somente algumas partes que ele selecionou. Porém, o trabalho tinha que ser tão bem feito que, tal como a última estrofe da poesia de Gregório de Matos, o fragmento, "não se sabendo parte deste todo... nos disse as partes todas deste todo". Oras, para realizar essa transformação, uma tarefa quase impossível, haja conhecimento teórico! E é este o desafio que Haroldo toma para si. Com seriedade, trabalhando verticalmente, em profundidade - e talvez sabendo que o tempo não é suficiente para abarcar, com essa profundidade radical, todo o horizonte bíblico ou todo o Fausto de Goethe -, ele reduz o objeto para aprofundar o estudo, para fazer incidir, como numa observação microscópica, um olhar que amplie as partes que constituem o todo. Se o braço é parte do todo, a célula é parte do braço e, numa seqüência de DNA de qualquer célula, está impresso o todo do organismo. No que Haroldo denomina de seu "canteiro de obras" - seu longo comentário que acompanha o trabalho interpretativo da tradução do Qohélet-, assistimos a uma magistral história de leituras que, como desdobramentos do texto original, devem também ser capazes de serem pressentidas na tradução. Sua tradução visa não apenas ser mais uma leitura do texto original mas, num empenho próximo do impossível, ser uma transferência, para o português, desse texto, na condição de potencialidade sobre a qual foram produzidas todas as leituras ao longo da história. Seu esforço aproxima-o a Benjamin, para quem todo trabalho intelectual é um trabalho de exegese e de comentário dos textos e das próprias realidades culturais, que também são levadas em consideração pelo seu crivo crítico, como se fossem textos. Haroldo, entre as leituras consagradas, seleciona aquelas que garantem a amplitude do leque exegético. Não há dúvida de que já esse labor é próximo do impossível, se cada leitura é uma singularidade. Mas ele parece aceitar, em sua seleção de autores, traduto- 


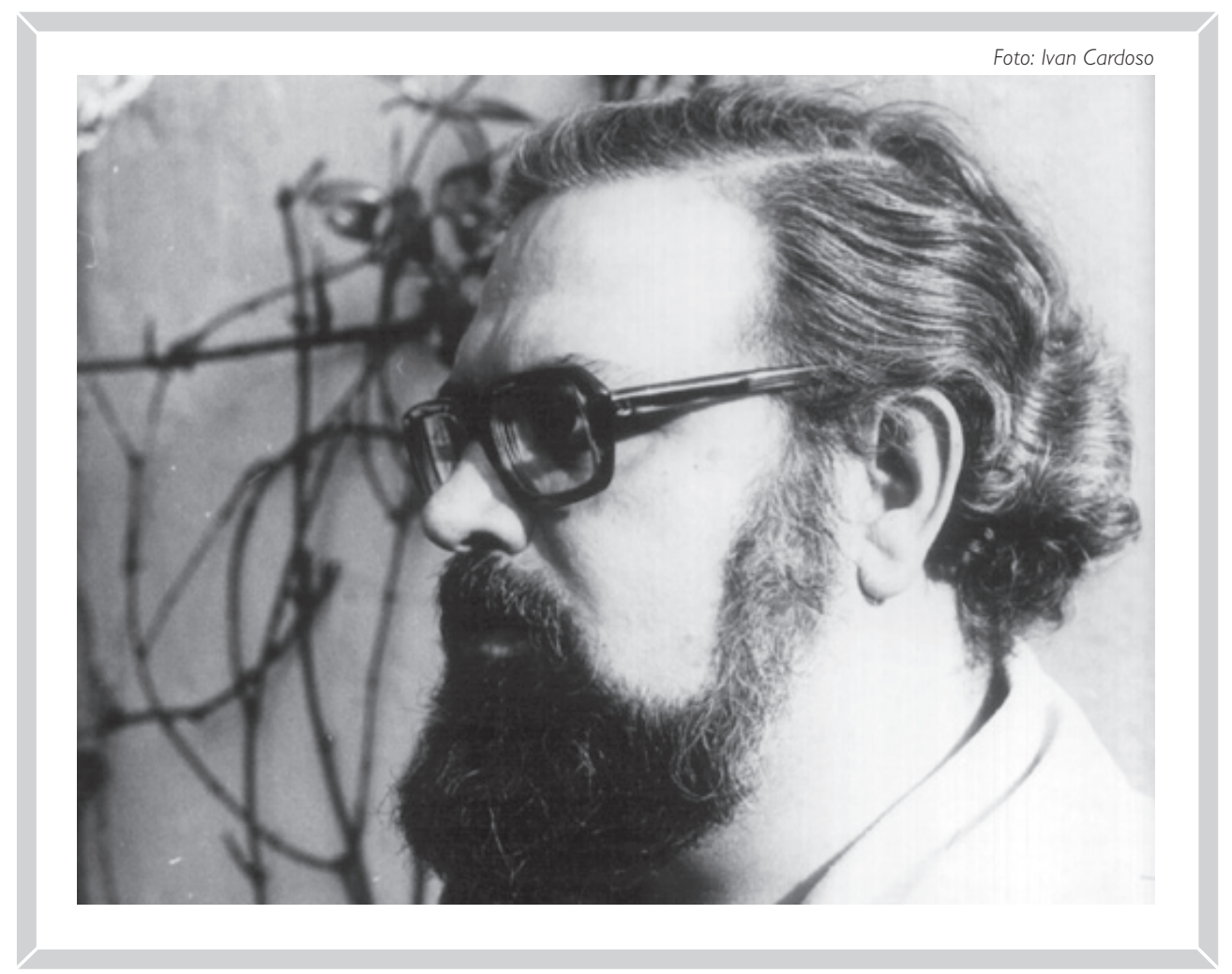

res e estudiosos do Qohélet, a noção de uma tradição que estaria melhor representada em um ou outro estudo. Assim, seleciona Guillaumont, para trazer a leitura, a apropriação da voz do Qohélet/O-que-Sabe pelo cristianismo oriental, que fundiu em territórios georgianos, armênios, sírios e etíopes, entre outros, gnose e judaísmo cristão; a história da tradução bíblica em português, que ganha a sua primeira versão completa, em três volumes, em 1753, pelo padre protestante João Ferreira de Almeida, tendo por base um hibridismo do original em hebraico com as versões em grego, latim e espanhol; a versão de Antônio Pereira de Figueiredo, padre católico, feita em 1790 a partir da Vulgata; a versão claretiana, que outorga à voz do Qohéle to sotaque e o gesto da longa tradição monástica beneditina; a Bíblia de Jerusalém, publicada sob a direção da Ècole Biblique de Jerusalem, que traduz o texto diretamente do original em hebraico e o faz acompanhar de glosas críticas, para além daquelas que explicitam a fé religiosa propriamente dita. Haroldo leva também em consideração todo o cipoal de traduções bíblicas em suas versões latina, grega, inglesa, francesa, italiana e alemã, sabendo, tal como Benjamin em "Sobre a Linguagem em Geral e sobre a Linguagem dos Homens" (3), que "cada língua comunica a si mesma" e comunica a essência espiritual que lhe corresponde, essência esta que se comunica "na língua, e não através da língua”. Porém, como Benjamin diz em “A Tarefa do Tradutor” (4), Haroldo busca “encontrar na língua a que se traduz uma atitude que possa despertar, em dita língua, um eco do original". Benjamin faz da busca dessa atitude a diferença entre o tradutor e o criador literário. O primeiro opera observando, a partir de fora, “a selva idiomática”. O segundo opera mergulhado nela. Entre tradutor e autor, estabelece-se uma diferença de intenções: a intenção de um autor, diz Benjamin, "é natural, originária e intuitiva, a do tradutor é uma derivada ideológica e definitiva: devido a que o grande motivo da integração das muitas línguas em uma só língua verdadeira é o que inspira a sua tarefa". E Benjamin arremata: "e justamente esta linguagem, em cuja intenção e em cuja descrição se encontra a única perfeição a que pode aspirar o filósofo,
3 W. Benjamin, Ângelus Novus, Barcelona, Edhasa, 1971, pp 145-66

4 Idem, ibidem, pp. 127-44. 
permanece latente no fundo da tradução".

Entre o hebraico e o português, Haroldo constrói um campo fraseológico, resultado de uma operação tradutória que permite, se não superar as diferenças entre as línguas, emparelhá-las. Para isso junta, à bibliografia de versões do Qohélet, dicionários e leitores críticos do texto, para além, é claro, das traduções no interior do campo judaico feitas em língua alemã, italiana, francesa e inglesa - ao todo, uma biblioteca de 65 volumes selecionados a dedo para the permitir mapear a contrapelo, por assim dizer, a história de leituras do Qohélet, indo em direção ao objeto textual original em suas dimensões verbivocovisual, das quais, como um bom concretista, Haroldo não abria mão. Ou seja, maximizando a dimensão dos sentidos que as múltiplas leituras foram desdobrando a partir do original, Haroldo pretende nada mais nada menos do que criar um campo semântico gráfico e fônico em português que seja análogo ao original em hebraico, e sobre o qual possa incidir toda essa pluralidade de leituras, tal como no original. Por isso é falso, a nosso ver, compreender a importância que Haroldo dá à dimensão do significante como sendo uma operação que reduz a dimensão do significado. Ao contrário, seu empenho em enfatizar a essência da linguagem poética do Qohélet o leva a querer compor um texto capaz de dizer tudo o que o original disse, sendo esta a tarefa impossível a que se propôs. Daí, sua luta contra o monologismo do sentido. Se a voz do Qohélet é enunciada, no mínimo, há 2.300 anos, se plurifurcou-se em leituras, a tradução de Haroldo pretende, de forma ecumênica, reunir toda essa dispersão. O rigor de sua operação de tradução assenta-se nessa intenção. Mais do que a leitura do texto original, seu trabalho de tradução - um verdadeiro ensaio sobre o Qohélet - é uma leitura das leituras desse texto.

Haroldo, o tradutor de Qohélet, continua sendo Haroldo, o poeta concretista? A nosso ver, a pergunta é legítima, uma vez que as experimentações atomísticas na fase mais radical dos poetas concretistas traziam consigo uma minimalização da lingua- gem que a tradução do Qohélet nos permite apreciar e, talvez, melhor significar. As contínuas transformações operadas pelas leituras do texto original não são re-visitadas por Haroldo, em seu "canteiro de obras", apenas para justificar uma ou outra opção tomada por ele em seu trabalho de tradução. É muito mais do que uma justificativa às opções de tradução o que obtemos ao acompanhar as reflexões de Haroldo. Quase cada versículoé dilatado de maneira que toda a complexidade ideacional que as diversas tradições de leitura foram construindo a partir da voz do Qohélet manifeste-se diante de nós. Alguns estudiosos do Qohélet, tais como Buzy, por exemplo, construíram a hipótese de que esse texto, na verdade, seria uma montagem de fragmentos advindos de diversos autores, sendo cada um destes, mais do que um sujeito particular, a voz e algo assim como um representante de uma visão de mundo e de homem no interior do campo judaico, no período da composição do Qohélet (5). Assim, estariam reunidas nesse texto, cheio de reviravoltas do pensamento sobre o mundo e os homens, a voz de um judeu pessimista, nomeado como Qohélet; a voz de um khakham, um sábio que realiza o elogio à sabedoria e a apresenta; a voz de um hassid, um piedoso que faz do temor a Deus a rocha principal sobre a qual se assenta sua relação com o mundo e com os homens e que observa, no processo da história, a progressão de um juízo suportado por uma Lei que avalia silenciosa mas definitivamente cada ato humano; e, ainda, a voz de um epilogista, que arremata o tex to tentando fazer convergir toda a sua complexidade numa direção definida. Ou seja, Qohélet seria uma multiplicidade de visões de mundo, entretecidas e legitimadas na constituição dessa voz. O próprio nome em hebraico, Qohélet, advém de palavras que têm em sua raiz as letras kof, khe e lamed, e cujos espectros de significados compreendem as ações de juntar, reunir, convocar, congregar, ganhando concretude na palavra Qehilá, que quer dizer comunidade, congregação. Qohélet seria uma reunião de vozes sobre a reunião dos homens, para uma 
reunião de homens. E a tradução de Haroldo radicaliza esse sentido, fazendo de seu exercício de leitura um campo de reunião de todas as leituras do Qohélet - a tradução como um exercício de convocação e reunião das diversas entoações que, ao longo de centenas de gerações, foram oferecidas à voz original, e que aqui são levadas em consideração, justapostas, coordenadas e subordinadas às potencialidades expressivas do original em hebraico, que Haroldo tenta performatizar em português. Daí vermos em sua tradução, em operação, o melhor da atividade concretista, que, através da parataxe - justaposição e coordenaçãoe da hipotaxe - subordinação -, tentava quebrar a estrutura linear do discurso, abolindo a temporalidade e permitindo assim a multiplicidade de leituras e pontos de vista. Na tradução do Qohélet, essa abolição da temporalidade dá-se, por assim dizer, levando completamente em consideração a própria temporalidade. Não que Haroldo historicize cada leitura. Ele não as contextualiza. Mas, obviamente, toda essa justaposição de múltiplas leituras e toda essa desmesurada ambição de fazê-las incidir sobre uma reconfiguração da linguagem original em português tornam o mínimo um suporte para o múltiplo.

No interessante texto de Donaldo Schüler, "Um Lance de Nadas na Épica de Haroldo" (6), o autor, ao se debruçar sobre a tradução do Qohélet feita por Haroldo, ressalta que seus comentários, “justapondo interpretações conflitantes, proporcionam aventura numa divertida refrega de significações, incursão nos labirínticos corredores da borgiana biblioteca de Babel. O sentido, desfazendo-se como a névoa, deixa a ossatura dos significantes que dizem tudo e, por isso mesmo, não dizem nada". A nosso ver, essa leitura precisa ser revista. Achar a justaposição de interpretações conflitantes “divertida” não nos parece um problema, desde que não percamos de vista a seriedade de cada uma delas. O que nos parece merecer uma revisão é deixar que o "nada" se sobreponha com facilidade a tudo que esses significantes podem dizer. Verdade que este é, inclusive, o próprio mote do Qohélet - "havel havalim amar Qohélet havel havalim hacol havel" ("névoa de nadas disse O-que-Sabe névoa de nadas tudo névoa nada", na tradução de Haroldo de Campos, ou "vaidade das vaidades - diz Qohélet - vaidade das vaidades, tudo é vaidade", na tradução da Bíblia de Jerusalém, que trabalha colada ao famoso "vanitas vanitatum, ominia vanitas" da Vulgata). Verdade também que muito da operação concretista em seus inícios visava, de acordo com o poeta boliviano-suíço Eugen Gomringer, evitar o solipsismo literário - o império absolutista dos sentidos. Philippe Buschinger, no artigo “"Desnazificação’ e Reconstrução” (7), contextualiza a operação concretista, situando historicamente o importante encontro de Eugen Gomringer e Décio Pignatari em novembro de 1955, na Escola Superior de Estética Industrial (Hochschule für Gestaltung), em Ulm, na República Federal da Alemanha, no período do pós-guerra. A nova atitude poética visaria superar o horror promovido pelo nacional-socialismo e ir ao encontro de "uma forma responsável, que o será justamente por sua utilidade para a comunidade humana e por sua integração no mundo contemporâneo". Trata-se de superar a "ditadura do eu" que, dentre outras variantes ideológicas, aportara no nazismo e no stalinismo; superar os particularismos e, como disse Gomringer, "fazer uma poesia que possa ser pensada universalmente, destinada a ser empregada por todo mundo [...] o poeta não pode mais ser aquele indivíduo solitário, que do alto de sua torre de marfim proclama ao mundo suas desesperadoras verdades universais - verdades que, afinal de contas, não dizem respeito senão a ele mesmo e a um punhado de fiéis ou eleitos obstinados na tarefa de decifrar a mensagem criptografada do mestre" (8). Emerge daí uma atitude diante do texto que relativiza a dimensão dos sentidos e passa a valorizar os seus aspectos formais, como modo de propiciar uma leitura e uma produção que supere os engajamentos parciais totalizantes, que tendem a reduzir os outros e todo mundo a uma particular leitura realizada. Mas esta relativização dos sentidos,

\footnotetext{
Texto extraido do site http:// www.schulers.com/donaldo/ haroldo.htm.

7 Philippe Buschinger, "'Desnazificação' e Reconstrução", Caderno Mais! Folha de $S$. Paulo, 08/12/96

8 ldem, ibidem
} 
a nosso ver, não deve significar a fácil vitória do nada sobre tudo. Como diz o próprio Donaldo Schüler, na operação de tradução de Haroldo de Campos, “a atenção se desloca do sentido para os sentidos, da unidade para a disseminação, do autor para as leituras", e assim o é, mas justamente por maximizar os sentidos: na luta contra o nada, sentimos o sopro do tudo. O Qohélet emerge com toda a sua força enunciadora em português por nos permitir re-visitar as múltiplas tradições de leituras que se abrem a nós para uma séria apreciação. Esta é, talvez, a impossível tarefa que Haroldo tomou para si, conduzindo-a bravamente. Toda essa colagem, montagem e simultaneidade de leituras, a nosso ver, não visa silenciá-las. Ao contrário, a névoa produzida, o adensamento realizado, resgata a seriedade das palavras do Qohélet e nos obriga, numa leitura estereofônica, a aceitar a difícil idéia de que a história multiplicou Qohélet em legítimas variações, mesmo quando uma parece afirmar o contrário da outra. Aqui, a soma dos opostos não anula, nem estes se deixam reduzir a um mínimo denominador comum. Só o poeta Haroldo para, numa operação que beira o milagre da realização de uma utopia, reunir os contrários, mantendo-os em tensão no todo.

Talvez o hebraico, a língua de origem do Qohélet, já tivesse sido levado em consideração quando do lançamento do Manifesto Concretista (9), em 1956, para a primeira exposição nacional de poesia concreta, no Museu de Arte Moderna de São Paulo. Ali, diz-se: "poesia concreta: tensão de palavras-coisas no espaço-tempo". "Palavras-coisas" remetem à palavra hebraica davar, cuja acepção de sentidos integra palavra e coisa. Davar é tanto um acontecimento quanto uma fala, tanto uma palavra quanto uma coisa. Da mesma maneira como, no relato bíblico, a criação do mundo e de tudo que dele faz parte é uma apresentação do davar de Deus, que vincula coisa e voz divina, a palavra-coisa concretista visa outorgar materialidade ao texto. No hebraico, a materialidade do referente apresenta-se com toda a sua potência.
Cada uma dessas letras que, ainda que não sejam ideogramas, guarda, como Haroldo lembrava, a profunda impressão de ser cinzelada em pedra, produz palavras que, em sua contenção, realizam uma escrita consonantal impregnada de sentidos que só emergem diante do leitor, que outorga a essa escrita as vogais necessárias para que, dentre a pluralidade dos sentidos possíveis, um deles se realize na leitura. A não utilização de signos para ritmar a leitura, tais como pontos e vírgulas, também contribui para que o texto assuma essa condição de obra em aberto e, dotado de ambigüidade, transforme o ato de ler, de interpretar, num desígnio do leitor, operação esta que o movimento concretista privilegia, ao fazer do leitor o principal responsável pelo funcionamento da poesia. É ele, em parceria com a obra, que deve arcar com a responsabilidade dos sentidos e conseqüências que consegue pôr em funcionamento no texto. Haroldo, em sua tradução, como nos velhos tempos da poesia concreta, evita o uso dos recursos gráficos da pontuação, criando um sistema visual, um dispositivo tipográfico que outorga ao texto uma "respiração prosódica" ou uma "pontuação do fôlego" (10) que permite, na leitura, levar em consideração "a articulação disjuntivoconjuntiva do 'sistema de acentos' chamado massorético (11), que percorre, como uma filigrana partitural, o original hebraico". Tal procedimento leva, mais do que a um resgate da cantilena original, a uma liberdade rítmica que fragiliza a estrutura linear do discurso e amplifica a ressonância de cada palavra. E é a partir desse desprendimento da estrutura linear que cada versículo da versão de Haroldo aproximase da condição de bloco de palavras - tal como no original -, que ganham agilidade umas em relação às outras não apenas por causa da ordem gramatical inerente que as congrega, mas também pela repercussão sonora de cada palavra - sua prosódia - no conjunto de palavras reunidas no versículo. Haroldo empenha-se por assegurar, em sua versão, a presença dessa espécie de contágio semântico entre as palavras que compõem os versículos - um dos aspectos dis- 
tintivos do texto bíblico que tem uma enorme implicação na própria operação hermenêutica, uma vez que é justamente a partir do efeito provocado pelas repetições sonoras dos fonemas nos vocábulos - as aliterações - e pela vizinhança de palavras semelhantes no som, porém diversas na significação - a paronomásia -, que grande parte do exercício de glosa etimológica bíblica (12), de apropriação de um sentido a partir do texto, foi realizada ao longo dos séculos pelos múltiplos exegetas que operaram com o original em hebraico ou em proximidade com ele, no interior das diversas correntes em que se inseriam. Um belo exemplo desse modo de exegese tão central na tradição judaica encontramos no Qohéle Rabá (13), uma antologia de exegeses rabínicas feitas em torno do Qohélet ao longo dos séculos, cuja primeira organização remonta ao séc. VIII d.C. Nesse comentário, um midrash (14) que pretende pôr de manifesto o sentido da palavra havel na frase já citada por nós - "havel havalim amar Qohelet havel havalim hacol havel" -, que abre e encerra o tex to do Qohélet, o comentador relaciona essa passagem à história de Caim e Abel, no Livro do Gênesis (15). Ocorre que, em hebraico, Caim (Kof-Iud - Num) é notavelmente semelhante à palavra Kiná (Kof - Iud - Num - Khei), que significa lamento. Além disso, o soletrar hebraico de Abel (Khei-Bet-Lamed) é o mesmo de havel, palavra que faz parte do versículo que citamos e que significa sopro, respiro, vapor. Assim, ao aproximar, pelas ressonâncias sonoras, a passagem de Caim e Abel (Gênesis 4) do versículo do Qohélet, um ilumina o outro, um re-significa o outro. Por um lado, os nomes de Caim e Abel parecem já conter o desfecho que a narrativa lhes reserva: a pena, o lamento que um dos filhos irá causar, e o prematuro fim do outro, o seu esvair-se antes de um tempo necessário, como vapor. Ao aproximar essas duas passagens, os nomes de Caim e Abel, desses filhos do homem em rivalidade, colocam-se como pano de fundo sobre o qual as reflexões do Qohélet se realizam: o estado da existência humana fora do paraíso, uma vida da qual fazem parte o lamento e o sopro e na qual a presença da morte suscita uma interrogação sobre o sentido da existência.

O que Haroldo pretende, através de todo o seu cuidado com a forma textual, é garantir minimamente em sua versão um texto que corresponda à orquestração original. Claro que, em português, soa diferente, e aqui radica o impossível de seu empenho. Porém, Haroldo consegue efeitos incríveis, ao selecionar meticulosamente cada palavra e, por outro lado, garantir um molde proverbial a cada versículo, atento à concisão formular sem reduzi-la a uma explicação, deixando que prevaleça o poder evocativo das imagens.

O texto do Qohélet se encerra do mesmo modo como se inicia: "névoa de nadas tudo névoa nada". Assim se despede o Qohélet, esse discurso do sábio rei que, entre a vida e a morte, observa o correr da história. É o saber daquele que se vai sem volta, mas que sabe que tudo permanece e dirige suas palavras aos que ficam - tão transitivos quanto ele, mas ao mesmo tempo tão permanentes na reiteração das gerações. Porque, apesar de tudo, apesar do constante martelar da morte, a figura humana permanece e adentra, em desdobramentos múltiplos, a história. Qohélet é aquele que sai de cena reconhecendo que era um sopro de passagem pela história da vida, um sopro no vento da história que a forma humana suscita, uma vaidade construindo a vaidade das vaidades no concreto da vida. $\mathrm{E}$, com a ajuda da leitura de Haroldo, agora sabemos que Qohélet/O-que-Sabe, o moribundo, o de olhos suficientemente frágeis para ver os escuros contornos que fazem parte do entorno em que está, em que viveu e do qual agora se despede para sempre, é névoa de nadas, um amontoado polifônico, uma névoa de fragmentos. Com Haroldo, o Qohélet se transforma, de voz sobre a estranheza da vida, em estranheza sobre a voz, a névoa. Porque vida e voz, em sua versão, são indissociáveis, tal como na fotografia o velho Haroldo, reunindo os livros, produz uma voz que aponta para os homens, os questiona sem portar uma solução, mas se oferece também como questão.
2 De acordo com Haroldo "o desocultar do conteúdo hebraico de palavras isoladas" (op. cit., p. 31 ).

13 CD-Rom The Soncino Midrash Rabbah Nova lork, The Soncino Press, 2001

$14 \mathrm{Em}$ hebraico, a palavro midrash serve tanto para no mear a interpretação da lei judaica quanto designar o gênero rabínico de exegeses bíblicas. A palavra midrash vem da raiz darash, que sign fica estudar, investigar, pesquisar, buscar.

150 relato de Caim e Abel faz parte, de acordo com os estu diosos da Bíblia, dos textos mais antigos, aqueles atributdos ao narrador J e datados do séc. X ou IX a.C. Portanto texto do Gênesis antecede em centenas de anos o do Qohélet. Mas um traço distintivo da hermenêutica rabínica é o de assumir a reunião de textos que é a Bíblia como uma unidade na qual cada uma das partes se comporta como braço, no poema de Gregório de Matos. 